\title{
Ustrojowe gwarancje praw zatrzymanego jako wzorce sądowej kontroli zatrzymania w polskim procesie karnym
}

\begin{abstract}
The purpose of the article is to draw attention to the fact that the Polish legal system features system-related guarantees of the rights of the detainee which are regulated in a multi-centric system of law, consisting of a set of constitutional norms and legalinternational norms, which create the models of judicial control of detention in a Polish criminal lawsuit. The article puts forward a thesis that the Polish system features the socalled dispersed control of constitutionality, which is erroneously considered a synonym of the concept of the so-called direct application of the constitution. The questions under discussion are analysed by means of a formal-dogmatic method. The article also discusses the possibility of the participation of assistant judges in the exercise of judicial control of detention, with reference to the recent modification of the system-based position of assistant judges.
\end{abstract}

Key words: detention, control of constitutionality, assistant judges

Przedmiotem artykułu jest wskazanie wzorców sądowej kontroli zatrzymania w polskim procesie karnym, którymi są ustrojowe gwarancje praw zatrzymanego określone $\mathrm{w}$ polskiej ustawie zasadniczej oraz w wiążących aktach prawa międzynarodowego. W artykule poruszono kwestię dopuszczalności przeprowadzania przez sądy powszechne „rozproszonej kontroli konstytucyjności” w kontekście unormowania praw zatrzymanego w aktach prawnych różnego rzędu. Wskazano, że kontrola konstytucyjności prawa jako kontrola abstrakcyjnych norm prawnych, która może prowadzić do derogacji norm prawnych z systemu prawa, należy w polskim porządku prawnym, z woli ustrojodawcy, do wyłącznej kognicji Trybunału Konstytucyjnego. Kolejno wskazano, że obowiązek bezpośredniego stosowania przepisów konstytucji wynikający z art. 8 ust. 2 
Konstytucji RP stanowi dla sądów powszechnych nakaz sprawowania wymiaru sprawiedliwości poprzez pryzmat konstytucyjnych wzorców ( $w$ tym wiążących wzorców z aktów prawa międzynarodowego), m.in. w drodze wykładni prokonstytucyjnej, współstosowania norm rangi konstytucyjnej i norm niższego rzędu, bądź zastosowanie zasady lex superior derogat legi inferiori. W artykule wskazuje się również na ostatnie zmiany pozycji ustrojowej asesorów sądowych wchodzących w skład sądu władnego w oznaczonej konfiguracji procesowej do sprawowania kontroli zatrzymania i postuluje się de lege ferenda, aby nominacja asesorów sądowych należała do konstytucyjnych prerogatyw Prezydenta.

\section{Wprowadzenie}

Polski ustrojodawca unormował w obowiązującej Konstytucji Rzeczypospolitej Polskiej z dnia 2 kwietnia 1997 r. (Dz.U. 1997, nr 78, poz. 483 z późn. zm.) dwojaki system gwarancji praw osób zatrzymanych. Po pierwsze wymienił w art. 41 ustawy zasadniczej podstawowe gwarancje praw osób zatrzymanych i osób pozbawionych wolności, które stanowią konstytucyjne gwarancje procesowe zatrzymanego $\mathrm{w}$ procesie karnym. Dopełnieniem tych gwarancji jest zasada proporcjonalności, która wyznacza granice dla zakresu możliwej ingerencji państwa w wolność osobistą człowieka. Po drugie ustrojodawca na podstawie art. 9 Konstytucji RP w zw. z art. 91 ust. 1 i 2 Konstytucji RP, poprzez nałożenie na Rzeczypospolitą Polskę obowiązku przestrzegania wiążącego ją prawa międzynarodowego, wprowadza do polskiego porządku prawnego międzynarodowe regulacje o charakterze gwarancyjnym dla osób zatrzymanych. W tym aspekcie gwarancje praw zatrzymanego zawarte w aktach prawa międzynarodowego i w przepisach Konstytucji RP tworzą łącznie ustrojowe gwarancje praw zatrzymanego. W przedmiotowym zakresie jednoczesne obowiązywanie norm konstytucyjnych i norm prawno-międzynarodowych w krajowym porządku prawnym powoduje konieczność uwzględnienia i współegzystowania obu systemów tworzących multicentryczny system prawny ${ }^{1}$.

W toku sądowej kontroli zatrzymania sąd nie opiera swego rozstrzygnięcia wyłącznie na przepisach Kodeksu postępowania karnego. Ustrojowe

${ }^{1}$ Zob. E. ŁĘTOwsKa: Multicentryczność wspótczesnego systemu prawa i jej konsekwencje. PiP 2005, z. 4; E. ŁĘTOWsKA: „Multicentrycznośc” systemu prawa i wykładnia jej przyjazna. W: Rozprawy prawnicze. Księga pamiatkowa Profesora Maksymiliana Pazdana. Red. L. OgiegŁo, W. PopioŁeK, M. Szpunar. Kraków 2005; A. Kalisz: Multicentryczność sytemu prawa polskiego a działalność orzecznicza Europejskiego Trybunatu Sprawiedliwości i Europejskiego Trybunału Praw Człowieka. W: RPEiS 2007, R. LXIX, z. 4, s. 35-49. 
gwarancje praw zatrzymanego, jako ustanowione m.in. w Konstytucji RP, determinują konieczność stosowania norm konstytucyjnych. Na mocy zaś art. 8 ust. 2 Konstytucji RP przepisy ustawy zasadniczej stosuje się bezpośrednio, chyba że Konstytucja stanowi inaczej. Przepis ten należy rozpatrywać w kontekście podziału norm konstytucyjnych na zasady, reguły i normy programowe. Normy reguły stosuje się wprost, jak np. art. 41 ust. 3 Konstytucji RP uzewnętrzniający się w obowiązku nakazania zwolnienia osoby zatrzymanej $\mathrm{w}$ razie przekroczenia obwarowanych terminów zatrzymania w tzw. systemie „48+24”. Normy zasady to normy, które dla swego zastosowania wymagają interpretacji. Należy podkreślić, że Konstytucja RP jest szczególną ustawą, gdyż jest nadrzędnym hierarchicznie źródłem prawa w polskim porządku prawnym. L. Garlicki przyjmuje, że sądowe stosowanie konstytucji przybiera trojaką formę: po pierwsze stosowania normy konstytucji jako podstawy rozstrzygnięcia (w sytuacji, gdy można ją samoistnie zastosować, a ustawy nie regulują danej materii), po drugie współstosowania normy konstytucyjnej i normy ustawowej w drodze wykładni przez sąd w sytuacji unormowania danej materii w konstytucji i w ustawie, gdzie będzie kilka możliwych logicznych rozwiązań - wtedy to sąd musi dokonać wykładni, która w najpełniejszy sposób koresponduje z treściami wyrażonymi przez normę konstytucyjną; po trzecie może polegać na stwierdzeniu konfliktu między normą konstytucyjną a ustawą, który to konflikt należy w pierwszej kolejności usunąć w drodze wykładni, a gdy będzie to niemożliwe, to należy podjąć działania do usunięcia przepisu ustawy z systemu prawa².

Podkreślić należy, że zarówno bezpośrednie stosowanie konstytucji, jak i wykładnia prokonstytucyjna nie jest formą rozproszonej kontroli konstytucyjności prawa. Wskazane zachowania są procesem interpretacyjnym bądź realizacją norm konstytucji wprost, bez usuwania przepisów rangi niższego rzędu względem Konstytucji RP z systemu prawa. O kontroli konstytucyjności można mówić, gdy dochodzi do kontroli norm prawnych, a nie kontroli faktu z prawem. Kontrola konstytucyjności polega na zbadaniu (porównaniu, zestawieniu) abstrakcyjnej normy prawnej pod kątem zgodności z normami konstytucyjnymi (z wzorcem kontroli). Współcześnie istnieją dwa modele kontroli konstytucyjności. L. Garlicki wskazuje, że pierwszy amerykański model rozproszonej kontroli konstytucyjności polega na kompetencji orzekania o zgodności ustaw z konstytucją, co powierzone jest wszystkim sądom, zatem kompetencja ta nie jest skoncentrowana w jednym organie sądowym. Drugi model - austriacki (kontynentalny), określany mianem kontroli skoncentrowanej, przejawia się w istnieniu szczególnego sądowego lub quasi-sądowego organu, trybu-

${ }^{2}$ L. Garlicki: Polskie prawo konstytucyjne. Wyd. 15. Warszawa 2011, s. 42. 
nału, sądu konstytucyjnego, który jest wyłącznie właściwy do orzekania zgodności ustaw z konstytucją ${ }^{3}$. O wyborze modelu kontroli konstytucyjności decyduje ustrojodawca, a nie prawoznawcy czy stosujący prawo. Polska Konstytucja przyjęła model skoncentrowanej kontroli zgodności prawa z konstytucją, którą rozumie się przez wyłączne uprawnienie Trybunału Konstytucyjnego do usuwania przepisów prawa z porządku krajowego $\mathrm{w}$ razie stwierdzenia jego niezgodności $\mathrm{z}$ ustawą zasadniczą. Kontrola konstytucyjności norm prawnych to kontrola abstrakcyjna, a sądowa kontrola zatrzymania jest kontrolą konkretną i faktyczną. Trybunał Konstytucyjny nie orzeka o zgodności z konstytucją faktów lub praktyk (stosowania prawa), ale o zgodności przepisów, które może usunąć z systemu prawa, dlatego nazywa się go sądem prawa lub negatywnym ustawodawcą. W świetle powyższego zarówno bezpośrednie stosowanie Konstytucji RP, jak i wykładnia prokonstytucyjna nie polega na usuwaniu przepisów z porządku prawnego, co należy do monopolu Trybunału Konstytucyjnego, lecz stanowi przejaw realizacji przepisu art. 8 ust. 2 Konstytucji RP, a w przypadku norm prawno-międzynarodowych - przepisu art. 91 ust. 3 Konstytucji RP.

Wobec powyższego sąd $\mathrm{w}$ toku sądowej kontroli zatrzymania, badając legalność zatrzymania, musi wziąć pod uwagę nie tylko przepisy postępowania karnego, ale również konstytucyjne gwarancje zatrzymanego, co, jak określił P. Kardas, należy do obowiązków stosujących prawo poprzez stosowanie Konstytucji RP bezpośrednio bądź dokonywanie wykładni przepisów zawartych w aktach prawnych porządku wewnętrznego w sposób, którego ostateczny rezultat w postaci zrekonstruowanej normy postępowania nie będzie sprzeczny z normami konstytucyjnymi (tzw. nakaz dokonywania wykładni zgodnie z Konstytucją, niem. Verfassungskonformeauslegung) ${ }^{4}$. Powyższe, zdaniem P. Kardasa, odnosi się także do norm konwencyjnych w postaci dyrektywy wykładni prawa wewnętrznego w sposób zgodny ze standardami określonymi w przepisach EKPC $^{5}$, a uznać należy, że do tego polski sąd jest zobowiązany na mocy art. 91 ust. 3 Konstytucji RP. Wykładnia prokonstytucyjna norm prawa międzynarodowego, według P. Kardasa, stanowi o wykorzystaniu wzorców wynikających z EKPC do rekonstrukcji wzorca konstytucyjnego ${ }^{6}$.

Sąd w toku sądowej kontroli zatrzymania dokonuje porównania zachowań uczestników postępowania karnego z wzorcami kontroli, który-

${ }^{3}$ Ibidem, s. 43-44.

${ }^{4}$ P. KaRdas: Uptyw określonego $w$ art. 41 ust. 3 Konstytucji $i w$ art. 248 §2 k.p.k. 24-godzinnego terminu a możliwość wydania postanowienia o tymczasowym aresztowaniu. CPKINP 2008, R. XII , z. 1, s. 124.

${ }^{5}$ Ibidem, s. 125.

${ }^{6}$ Ibidem, s. 129. 
mi są przepisy regulujące instytucję zatrzymania. Wzorcami przedmiotowej kontroli są Kodeks postępowania karnego oraz ustawy szczególne regulujące sposób postępowania podmiotów przeprowadzających czynność zatrzymania. Wzorcami kontroli są nie tylko przepisy stanowiące o sposobie, przesłankach i podmiotach przeprowadzających zatrzymanie, ale także ustrojowe gwarancje praw osób zatrzymanych.

\section{Konstytucyjne gwarancje praw zatrzymanego}

Prawo do wolności to jedno z fundamentalnych praw człowieka, którego ochrona jest głęboko „zakorzeniona” w obowiązującej Konstytucji RP. Już w preambule do ustawy zasadniczej ustanowiono Konstytucję Rzeczypospolitej Polskiej jako prawa podstawowe dla państwa, oparte m.in. na poszanowaniu wolności, a wszyscy, którzy dla dobra Trzeciej Rzeczypospolitej tę Konstytucję będą stosowali, zostali wezwani, aby czynili to, dbając o zachowanie przyrodzonej godności człowieka, jego prawa do wolności i obowiązku solidarności z innymi, a poszanowanie tych zasad mieli za niewzruszoną postawę Rzeczypospolitej Polskiej.

Do konstytucyjnych gwarancji praw zatrzymanego należą: ustanowienie zasad i trybu zatrzymania w akcie rangi ustawowej (art. 41 ust. 1 Konstytucji RP), prawo do odwołania się do sądu celem niezwłocznego ustalenia legalności zatrzymania oraz prawo do niezwłocznego powiadomienia rodziny lub osoby wskazanej przez zatrzymanego (art. 41 ust. 2 Konstytucji RP), niezwłoczne i zrozumiałe pouczenie zatrzymanego o przyczynach zatrzymania, obowiązek przekazania zatrzymanego do dyspozycji sądu w ciągu 48 godzin od chwili zatrzymania, obowiązek zwolnienia zatrzymanego, jeżeli w ciagu 24 godzin od przekazania do dyspozycji sądu nie zostanie mu doręczone postanowienie sądu o tymczasowym aresztowaniu wraz z przedstawionymi zarzutami (art. 41 ust. 3 Konstytucji RP), obowiązek traktowania zatrzymanego w humanitarny sposób (art. 41 ust. 4 Konstytucji RP), prawo do odszkodowania z tytułu bezpodstawnego zatrzymania (art. 41 ust. 5 Konstytucji RP).

Przepis art. 41 ust. 3 Konstytucji RP uważa się za lex specialis w stosunku do przepisu art. 41 ust. 2 Konstytucji RP, jako ustanawiający dodatkowe gwarancje dla zatrzymanego w postaci prawa do informacji o przyczynach zatrzymania, temporalnego ograniczenia w zakresie stosowania zatrzymania, prawa do przekazania do dyspozycji sądu ${ }^{7}$.

W nauce prawa przepis art. 41 ust. 3 Konstytucji RP interpretuje się w ten sposób, że osoba zatrzymana powinna być w sposób zrozumia-

${ }^{7}$ P. Wiliński, P. Karlik. W: Konstytucja RP, Komentarz do art. 1-86. T. 1. Red. M. SAfJAn, L. BoseK. Warszawa 2016, Legalis, art. 41, nb. VII.1. 
ły, komunikatywny, w razie potrzeby z udziałem tłumacza (czy to języka migowego czy też obcego) poinformowana o przyczynach zatrzymania, a organ zatrzymujący powinien upewnić się, czy osoba zatrzymana zrozumiała komunikat i w razie wątpliwości winna powtórzyć informację o przyczynach zatrzymania, a wskazany obowiązek informacyjny musi być zadoścuczyniony niezwłocznie, to jest „bez nieuzasadnionej zwłoki"8. Wymóg niezwłoczności informacji o przyczynach zatrzymania uważa się w nauce prawa jako wywiązanie się $\mathrm{z}$ obowiązku bez zbędnej zwłoki, czyli tak szybko, jak to tylko jest możliwe w istniejącym układzie okoliczności i po uwzględnieniu obiektywnych przeszkód albo obowiązków9 ${ }^{9}$ Podkreśla się, że prawo do uzyskania zrozumiałej i niezwłocznej informacji o przyczynach zatrzymania należy odróżnić od przedstawienia zatrzymanemu stawianych mu zarzutów ${ }^{10}$.

Czas zatrzymania określony jest $\mathrm{w}$ art. 41 ust. 3 Konstytucji RP i bezwzględnie nie może być przekroczony, a zatrzymywanie osób do 48 godzin bez oddania do dyspozycji sądu może być w pewnych warunkach uznane za nękanie i rodzaj represji, co zauważano w działaniach organów PRL ${ }^{11}$.

Przekroczenie terminów określonych $\mathrm{w}$ art. 43 ust. 1 Konstytucji RP obliguje bezwzględnie do zwolnienia zatrzymanego ${ }^{12}$ i stanowi naruszenie konstytucyjnych gwarancji zatrzymanego, co musi być przestrzegane rygorystycznie i bez względu na czas przekroczenia, chociażby minutowy ${ }^{13}$.

Ocenę zasadności zatrzymania przeprowadza się również z uwzględnieniem konstytucyjnej zasady proporcjonalności ${ }^{14}$, związanej z przepisem art. 31 ust. 3 Konstytucji RP, w świetle którego ograniczenia w zakresie korzystania z konstytucyjnych wolności i praw mogą być ustanawiane tylko w ustawie i tylko wtedy, gdy są konieczne w demokratycznym pań-

${ }^{8}$ B. BanaszaK: Konstytucja Rzeczypospolitej Polskiej. Komentarz. Wyd. 2. Warszawa 2012; art. 41, nb. 8; P. WiLIŃsKI, P. KarLIK. W: Konstytucja RP, Komentarz..., Legalis, art. 41 , nb. VII. 2.

${ }^{9}$ Ibidem, art. 41, nb. VII. 2.

${ }^{10}$ Ibidem.

${ }^{11}$ B. BANASZAK: Konstytucja..., Legalis, art. 41, nb. 10.

12 B. BanaszaK: Konstytucja..., Legalis, art. 41, nb. 11; P. WilińsKi, P. Karlik. W: Konstytucja RP, Komentarz..., Legalis, art. 41, nb. VII. 3.

${ }^{13}$ P. WiLIŃski, P. Karlik. W: Konstytucja RP, Komentarz..., Legalis, art. 41, nb. VII. 3.

${ }^{14} \mathrm{~K}$. MARSZAe, J. ZaGRoDNIK: Zatrzymanie wtaściwe z perspektywy sadowej kontroli postępowania przygotowawczego. W: Czynności dochodzeniowo-śledcze i działania operacyjne policji a rola sqdu $w$ postępowaniu przygotowawczym. Materiaty pokonferencyjne. Red. S. Lelental, J. Kudrelek, I. Nowicka. Szczytno 2008, s. 98-99; K. Eichstaedt. W: Kodeks postępowania karnego. Komentarz. T. 1. Wyd. 2. Red. D. ŚwIECKI et al. Warszawa 2015, LEX, art. 246, nb. 3; L. PAPRZYCKI. W: Komentarz aktualizowany do art. 1-424 ustawy $z$ dnia 6 czerwca 1997 r. Kodeks postępowania karnego (Dz.U.97.89.555). Red. L. PAPRZYCKI, J. Grajewski, S. Steinborn. LEX, art. 246, nb. 2; T. GrzegorCzyK: Kodeks postępowania karnego. Artykuty 1-467. T 1. Wyd. 6. Warszawa 2014, LEX, art. 246, nb. 3. 
stwie dla jego bezpieczeństwa lub porządku publicznego, bądź dla ochrony środowiska, zdrowia i moralności publicznej, albo wolności i praw innych osób. Ograniczenia te nie mogą naruszać istoty wolności i praw. Ponadto kryterium oceny legalności musi być powiązane z zakazem tortur, okrutnego, nieludzkiego lub poniżającego traktowania (art. 40 Konstytucji RP).

Orzecznictwo Trybunału Konstytucyjnego wskazuje, że art. 41 ust. 2 Konstytucji RP wyznacza, iż kontrola legalności pozbawienia wolności obejmuje: legalność, przesłanki i tryb podjęcia decyzji o pozbawieniu wolności, a także sposób realizacji i czas trwania pozbawienia wolności ${ }^{15}$. Ocena legalności ma być sprawowana możliwie szeroko, zgodnie z zasadami interpretowania konstytucyjnych określeń, a badaniu sądu podlega istnienie podstaw zatrzymania, ocena dopuszczalności in concreto zatrzymania, prawidłowości zastosowanej procedury, potrzeby dalszego stosowania zatrzymania ${ }^{16}$. Zwolnienie osoby bezpodstawnie zatrzymanej ma być zapewnione przez niezwłoczne wydanie orzeczenia, a sądowa kontrola zatrzymania osoby po zwolnieniu osoby zatrzymanej ma zapewnić sprawdzenie legalności zatrzymania, a w razie wykazania nieprawidłowości zapewnić jej prawo wynikające z art. 41 ust. 5 Konstytucji RP do dochodzenia roszczeń, jak również ma zapobiec podobnym naruszeniom prawa w przyszłości ${ }^{17}$, co wpisuje się w funkcję prewencyjną sądowej kontroli (zwanej też funkcją stymulacyjną) ${ }^{18}$.

Prawo do wysłuchania osoby pozbawionej wolności (art. 41 ust. 2 Konstytucji RP) jest związane z prawem do sądu ${ }^{19}$, co powinno być rozpatrywane w procedurze sądowej ukształtowanej zgodnie z wymogami jawności i sprawiedliwości ${ }^{20}$.

Konstytucjonaliści przychylają się do poglądu wyrażonego w cytowanych orzeczeniach Trybunału Konstytucyjnego, iż prawo odwołania się

${ }^{15}$ Wyrok TK z dnia 6 grudnia 2004 r., SK 29/2004, VII. 2; Wyrok TK z dnia 11 czerwca 2002 r., SK 5/2002.

${ }^{16}$ Wyrok TK z dnia 6 grudnia 2004 r., SK 29/2004; TK cytujący za: P. SARNECKI. W: Konstytucja Rzeczpospolitej Polskiej. Komentarz. T. 3. Warszawa 2003, art. 41 s. 7; por. też P. WiLIŃsKi, P. Karlik. W: Konstytucja RP, Komentarz..., Legalis, art. 41, nb. V. 1.

${ }^{17}$ Wyrok TK z dnia 11 czerwca 2002 r., SK 5/2002; B. BANASZAK: Konstytucja..., Legalis, art. 41 , nb. 6.

${ }^{18}$ Por. A. GABERLE: Funkcje kontroli instancyjnej $w$ procesie karnym (zagadnienia podstawowe). W: Środki zaskarżenia w procesie karnym. Ksiegga pamiatkowa ku czci prof. Zbigniewa Dody. Red. A. Gaberle, S. Waltoś. Kraków 2000, s. 33; K. MarsZaŁ: Proces karny. Zagadnienia ogólne. Wyd. 2 uzupełnione. Katowice 2013, s. 81; P. KęPA, J. ZAGRoDNIK: Sądowa kontrola organów ścigania karnego $w$ postępowaniu przygotowawczym. Śląska Biblioteka cyfrowa. Źródło: https://www.sbc.org.pl/dlibra/publication/269652/edition/255095/content?ref= desc [dostęp: 7.01.2018], s. 25-26, 82, 85, funkcja prewencyjna lub stymulacyjna.

${ }^{19}$ B. BanaszaK: Konstytucja..., Legalis, art. 41, nb. 6.

${ }^{20}$ P. WilińsKi, P. Karlik. W: Konstytucja RP, Komentarz..., Legalis, art. 41, nb. V. 1; zob. P. WiLIŃski: Proces karny w świetle konstytucji. Warszawa 2011, s. 196. 
do sądu „implikuje przyznanie sądowi odpowiednich uprawnień w zakresie prowadzenia postępowania dowodowego w celu wszechstronnego zbadania okoliczności pozbawienia wolności"21.

Zakres prawa do odszkodowania na gruncie polskiej Konstytucji zdaniem konstytucjonalistów obejmuje zarówno pojęcia odszkodowania i zadośćuczynienia uregulowane w Kodeksie cywilnym, przez co zakres tego prawa obejmuje szkodę doznaną przez bezprawne pozbawienie wolności (damnum emergens) oraz utracone z tego powodu korzyści (lucrum caesans), jak i możność odszkodowania za krzywdę wynikłą z bezprawnego zatrzymania ${ }^{22}$.

\section{Prawno-międzynarodowe gwarancje praw zatrzymanego}

Przepis art. 9 Konstytucji RP stanowi, że Rzeczpospolita Polska przestrzega wiążącego ją prawa międzynarodowego. Z kolei na mocy art. 91 ust. 1 i 2 Konstytucji RP po zadośćuczynieniu obowiązku ratyfikacji umowy międzynarodowe (pierwotne prawo międzynarodowe) stanowią część krajowego porządku prawnego i są bezpośrednio stosowane, chyba że ich stosowanie zależne jest od wydania ustawy. Wobec powyższych przepisów umowy ratyfikowane za uprzednią zgodą wyrażoną w ustawie mają pierwszeństwo przed ustawami, przy czym na mocy art. 8 ust. 1 Konstytucji RP to polska ustawa zasadnicza nadal jest najwyższym prawem w Rzeczypospolitej Polskiej. Pochodne prawo międzynarodowe ma pierwszeństwo przed polskimi ustawami w razie kolizji norm, jeżeli wynika to $\mathrm{z}$ wiążącego ratyfikowanego międzynarodowego prawa pierwotnego (art. 91 ust. 3 Konstytucji RP). Oznacza to, że do polskiego porządku prawnego należą m.in. takie akty jak: Powszechna Deklaracja Praw Człowieka, Konwencja o Ochronie Praw Człowieka i Podstawowych Wolności, Międzynarodowy Pakt Praw Obywatelskich i Politycznych, Karta Praw Podstawowych UE.

Szczególną rolę w zakresie prawno-międzynarodowych gwarancji praw zatrzymanego ma orzecznictwo Europejskiego Trybunału Praw Człowieka, który orzeka na podstawie Konwencji o Ochronie Praw Człowieka i Podstawowych Wolności. Analiza konkretnych przypadków pozwala na wskazanie przykładów zachowań, które w ocenie ETPC naruszają EKPC.

${ }^{21}$ B. BANASZAK: Konstytucja..., Legalis, art. 41, nb. 6; Wyrok TK z dnia 11 czerwca 2002 r., SK 5/02, OTK-A 2002, nr 4, poz. 41.

${ }^{22}$ P. WilińsKi, P. KarliK: W: Konstytucja RP, Komentarz..., Legalis, art. 41, nb IX. 1. 
W sprawie Lewandowski i Lewandowska p. Polsce (Skarga nr 15562/02) $)^{23}$ ETPC podkreślił, że w przypadku, gdy osoba zatrzymana przez policję jest w dobrym zdrowiu, a po zwolnieniu stwierdza się u takiej osoby obrażenia, to na państwie spoczywa obowiązek udzielenia przekonującego wyjaśnienia, co spowodowało te obrażenia, a zaniedbanie tegoż obowiązku stanowi naruszenie artykułu $3 \mathrm{EKPC}^{24}$. Orzecznictwo ETPC wskazuje, że użycie środków przymusu bezpośredniego związane z art. 3 EKPC może mieć miejsce tylko wówczas, gdy środki te są niezbędne i nie są nadmierne ${ }^{25}$. Użycie siły fizycznej wobec osoby pozbawionej wolności, które nie było bezwzględnie spowodowane zachowaniem tej osoby w ocenie ETPC umniejsza godność ludzką i zasadniczo narusza prawo określone $\mathrm{w}$ art. $3 \mathrm{EKPC}^{26}$. W toku rozpatrywania przedmiotowej skargi ETPC uznał wyjaśnienia Rządu RP za niewystarczające, zwłaszcza wobec niespójnych opinii lekarzy co do powstania obrażeń u zatrzymanego (który był dotkliwie pobity) i braku informacji na czym oparł się prokurator, a ponadto z uwagi na zlekceważenie zeznań świadka, który widział z posesji zdarzenie, przez co sumarycznie Trybunał nie znalazł podstaw do stwierdzenia, że w tym przypadku użycie siły fizycznej było konieczne z powodu zachowania syna skarżących, a mając na uwadze charakter obrażeń, Trybunał uważał, że Rząd RP nie przedstawił przekonujących czy wiarygodnych argumentów, które stanowiłyby podstawę do wyjaśnienia lub uzasadnienia stopnia siły użytej podczas zatrzymania. ETPC uznał, że siła użyta przez Policję była nadmierna i nieuzasadniona w okolicznościach sprawy, co naruszyło art. 3 EKPC odnośnie nieludzkiego i poniżającego traktowania zatrzymanego syna skarżących ${ }^{27}$.

W sprawie Bernatowicz p. Polsce (12 stycznia 2010 r., skarga nr 69122/01) ETPC stwierdził, że wymóg zaistnienia „uzasadnionego podejrzenia" (franc. reasonableness) popełnienia przestępstwa, jako warunek zatrzymania, stanowi podstawowe zabezpieczenie przed arbitralnym pozbawieniem wolności. Dalej ETPC podniósł, że „podejrzenie popełnienia przestępstwa" $\mathrm{z}$ art. 5 ust. 1c EKPC nie wymaga, aby organy ści-

${ }_{23}$ Za: http://isp.policja.pl/isp/prawa-czlowieka-w-poli/orzecznictwo/1351,Sprawa-Le wandowski-i-Lewandowska-przeciwko-Polsce.html [dostęp: 30.07.2017].

${ }^{24}$ Ibidem, Lewandowski i Lewandowska p. Polsce, nb. 58, gdzie ETPC wskazuje analogicznie Selmouni p. France [GC], §87, wyrok z dnia 22 września 1993 r. w sprawie Klaas p. Niemcom, §23-24, seria A, nr 269 oraz wyrok w sprawie 29462/95 Rehbock p. Slovenii, §68-78, ECHR 2000-XII.

25 Ibidem, nb. 59, gdzie ETPC wskazuje Rehbock, wyrok z dnia 22 maja $2001 \mathrm{r}$. w sprawie 22279/93 Altay p. Turcji, z dnia 12 kwietnia 2007 r. w sprawie 48130/99 Ivan Vasilev p. Bułgarii.

${ }^{26}$ Ibidem, nb. 59, gdzie ETPC wskazuje wyrok z dnia 4 grudnia 1995 r. w sprawie Ribitsch p. Austrii, §38, Seria A, nr 336.

${ }^{27}$ Ibidem, nb. 60-66. 
gania w momencie zatrzymania posiadały wystarczające dowody, takie, jakimi należy dysponować przy postawieniu zarzutów. ETPC uznał, że celem „rozpytania” zatrzymanego jest uzyskanie potwierdzenia przypuszczenia popełnienia czynu zabronionego lub rozwianie istniejących wobec niego podejrzeń, będących podstawą zatrzymania. Wobec tego Trybunał stwierdził, że fakty, które dają podstawę do podejrzeń wymaganych przy zatrzymaniu, nie muszą być ustalone na tym samym poziomie jak te, które usprawiedliwiają skazanie czy nawet przedstawienie zarzutów, które stanowi dopiero kolejny etap postępowania karnego, a na kanwie wymienionej sprawy ETPC uznał zarzut naruszenia art. 5 EKPC za oczywiście bezzasadny, albowiem sąd polski poczynił szerokie ustalenia, nie przekroczono 48 godzin od zatrzymania i zatrzymanie przebiegało zgodnie z prawem ${ }^{28}$.

W sprawie Garlicki p. Polsce (skarga nr 36921/07) zawisłej przed ETPC stwierdzono naruszenie art. 5 Konwencji, ponieważ o zastosowaniu tymczasowego aresztowania orzekał asesor ${ }^{29}$.

Instytucja asesora sądowego została usunięta z polskiego porządku prawnego na mocy Wyroku Trybunału Konstytucyjnego z dnia 24 października 2007 r., SK 7/06, którego wejście w życie odroczono na 18 miesięcy, lecz polski ustawodawca przywrócił tę instytucję. Ustawa prawo o ustroju sądów powszechnych w brzmieniu po 20 czerwca 2017 r. stanowi, że asesorzy sądowi orzekać mogą wyłącznie w sądach rejonowych, a z ich kognicji wyłącza się sądową kontrolę zaniechania ścigania karnego $\mathrm{w}$ postępowaniu przygotowawczym i stosowanie tymczasowego aresztowania przy oddaniu osoby zatrzymanej do dyspozycji sądu wraz $\mathrm{z}$ wnioskiem o zastosowanie tymczasowego aresztowania oraz sprawy rodzinne i opiekuńcze. Asesor sądowy w myśl obowiązującej p.u.s.p. sędzią nie jest, lecz powierza się mu pełnienie obowiązków sędziego na 5 lat, przy czym sam asesor powoływany jest dożywotnio, a jego gwarancje procesowe są ukształtowane na wzór gwarancji przysługujących sędziom z pewnymi ograniczeniami w zakresie samorządu sędziowskiego. Nadal asesor sądowy będzie mógł stosować tymczasowy areszt na wniosek prokuratora, gdy nie będzie on połączony z oddaniem do dyspozycji sądu osoby zatrzymanej, oraz będzie mógł przedłużać stosowanie aresztu. Warto odnotować, że pierwotna regulacja przywracająca asesurę zabraniała asesorom podejmowania postanowień w przedmiocie tymczasowe-

${ }^{28}$ Za: „Przegląd Orzecznictwa Europejskiego dotyczącego spraw karnych” 2010, z. 1-2 (obejmuje okres 1 stycznia-31 lipca 2010 r.). Oprac. M. WĄSEK-WIADEREK. Biuro Studiów i Analiz Dział Prawa Europejskiego, s. 15-17. Źródło: http://www.sn.pl/orzecznictwo/ Orzecz_Euro_Karne/Orzecz_Euro_Karne_01-02_2010.pdf [dostęp: 30.07.2017].

$29 \mathrm{Za}:$ http://www.hfhr.pl/wazne-orzeczenia-etpcz-w-polskich-sprawach-3/ [dostęp: 30.07.2017]. 
go aresztowania w toku postępowania przygotowawczego aż do wydania aktu oskarżenia. Trybunał Konstytucyjny podkreślał, że podstawą jest sprawowanie wymiaru sprawiedliwości przez sędziów, przy czym wyjątki od tej zasady musiałyby być uwarunkowane: po pierwsze lepszą realizacją podmiotowego prawa do sądu z art. 45 ust. 1 Konstytucji RP, a po drugie spełnieniem istotnych materialnych warunków, od których uzależniona jest bezstronność, niezależność i niezawisłość sądu. Zdaniem Trybunału Konstytucyjnego poprzednia regulacja asesury nie gwarantowała nieusuwalności i była decyzją uznaniową Ministra Sprawiedliwości. W ocenie Trybunału Konstytucyjnego czas powołania nie musi być dożywotni, ale musi gwarantować stabilność, dla przykładu wskazano, że ETPC określa powinność minimum 3 lat asesury ${ }^{30}$. Przepis art. $2 \$ 1$ a p.u.s.p. nie wyłącza sprawowania sądowej kontroli zatrzymania przez asesora sądowego, jeżeli kontrola ta nie łączy się z rozpoznaniem wniosku o zastosowanie tymczasowego aresztowania wobec zatrzymanego oddanego do dyspozycji sądu. Ocena prawnoustrojowej pozycji asesorów sądowych wymaga osobnego opracowania, jednakże można obecnie poczynić dwie konstatacje. Po pierwsze wydaje się, że model asesury wyrażony przed wejściem w życie Ustawy z dnia 10 maja 2018 r. o zmianie ustawy - Prawo o ustroju sądów powszechnych, ustawy o Sądzie Najwyższym oraz niektórych innych ustaw ${ }^{31}$ (tj. przed 6 czerwca 2018 r.) uczynił decyzję Ministra Sprawiedliwości o mianowaniu asesora sądowego „decyzją związaną” (art. $106 \mathrm{i} \$ 1$ i $\$ 2$ p.u.s.p.) na co wskazuje norma iuris cogentis ,mianuje" i określenie obiektywnych przesłanek determinujących powzięcie tej decyzji na podstawie przedłożonych list przez Dyrektora KSSIP z wynikami egzaminu sędziowskiego i oświadczenia asesora o wyborze miejsca służbowego (siedzib). Wydaje się, że dotychczasowe regulacje (tj. obowiązujące przed wejściem w życie noweli USP z 10 maja 2018 r.) zapewniały analogiczne do przypadku sędziów materialne gwarancje niezależności i niezawisłości (w tym gwarancję nieusuwalności, na co zwracał uwagę Trybunał Konstytucyjny). Po drugie wydaje się, że słuszny był zamysł mianowania asesorów sądowych przez Prezydenta, analogicznie do jego uprawnienia do mianowania sędziów. Przemawia za tym m.in. silny mandat Prezydenta, oparty na legitymacji prezydenta wybieranego w wyborach bezpośrednich, oraz polska historia konstytucyjna. Wydaje się, że na krytykę zasługuje niewłączenie decyzji o mianowaniu asesorów sądowych do enumeratywnego katalogu prerogatyw Prezydenta, których - według brzmienia przepisu art. 144 ust. 2 Konstytucji RP oraz we-

${ }^{30}$ Red. L. Garlicki, M. DerlatKa, M. Wiącek: Na straży państwa prawa. Trzydzieści lat orzecznictwa Trybunatu Konstytucyjnego. Warszawa 2016, s. 659-671 [wyrok - P.K.], s. 671-689 [komentarz M. DERLATKa - P.K.].

${ }^{31}$ Dalej zwana nowelą USP z 10 maja 2018 r. 
dług przeważającego stanowiska doktryny prawa konstytucyjnego - nie można wykładać rozszerzająco ${ }^{32}$. Bez uzyskania kontrasygnaty Prezesa Rady Ministrów akt urzędowy Prezydenta nie „wywołuje odpowiedniego skutku w systemie prawnym", a Premier takim wnioskiem nie jest $\mathrm{w}$ żadnej mierze związany ${ }^{33}$. Ponadto w doktrynie prawa konstytucyjnego jawi się pogląd, że ustawa zwykła nie może określać, które kompetencje Prezydenta nie podlegają obowiązkowi uzyskania współpodpisu, ani też nie może stanowić, które kompetencje zwolnione są z tego wymogu ${ }^{34}$. W tym stanie rzeczy de lege lata ${ }^{35}$ decyzja Prezydenta RP o mianowaniu asesorów pozostaje zależna od dyskrecjonalnej decyzji Prezesa Rady Ministrów. Tym samym pozostaje zależna od wyrażenia woli przez przedstawiciela władzy wykonawczej, nie mającego dotychczas ani legitymacji, ani prawnej kompetencji do udziału w procesie decyzyjnym mianowania członków władzy sądowniczej. Wydaje się zatem, że wybór osób niebędących sędziami, a sprawujących wymiar sprawiedliwości ponownie przestał zależeć od obiektywnych przesłanek. Konstrukcja powoływania asesorów nadana nowelą USP z 10 maja 2018 r. uzależnia bowiem ważność aktu urzędowego Prezydenta od swobodnej, w pełni nieograniczonej decyzji Prezesa Rady Ministrów. Tym samym wpływ na kształtowanie władzy sądowniczej został uzależniony od głosu przedstawiciela władzy wykonawczej, który w historii polskiego konstytucjonalizmu nie miał do tej pory wpływu na proces kształtowania władzy sądowniczej. Można hipotetycznie wyobrazić sobie sytuację sanowania tego stanu rzeczy w drodze wykreowania zwyczaju konstytucyjnego w postaci braku odmowy kontrasygnaty przedmiotowej decyzji Prezydenta, lecz wobec zaistniałego precedensu konstytucyjnego w postaci Postanowienia Prezydenta RP nr 1130.9.2016 z dnia 22 czerwca 2016 r. (M.P. z 21.7.2016, poz. 696) o odmowie powołania dziesięciu osób na stanowiska sędziowskie nie ma żadnych gwarancji, że Prezes Rady Ministrów nie skorzysta z analogicznej sposobności. W tym stanie rzeczy wydaje się, że nowelizacja ta przywra-

32 B. BanaszaK: Konstytucja..., Legalis, art. 144, nb. 3; P. WilińsKi, P. KARLIK. W: Konstytucja RP..., Legalis, art. 144, nb. III. 2; R. BALICKI: Komentarz do art. 144 Konstytucji Rzeczypospolitej Polskiej. W: Konstytucja Rzeczypospolitej Polskiej. Komentarz. Red. M. HaczKowsKa. Warszawa 2014, nb. 5; odmiennie: P. SARnecki: Prezydent Rzeczypospolitej Polskiej. Komentarz do przepisów. Kraków 2000, art. 144 - upatrujący w funkcji Prezydenta, tj. działania jako „gwarant ciągłości władzy państwowej”, szerokiej interpretacji katalogu jego prerogatyw, wbrew wzorcowej interpretacji takiej konstrukcji prawnej (zasada-wyjątek). Dopuszczający zwolnienie z wymogu kontrasygnaty kompetencji analogicznych do wymienionych w art. 144 ust. 3, przy których istnieje identyczne ratio legis ich wyłączenia.

${ }^{33}$ P. WilińsKi, P. KARLIK. W: Konstytucja RP..., Legalis, art. 144, nb. III. 2.

${ }^{34}$ Ibidem, Legalis, art. 144, nb. III.2; A. FranKIEWICZ: Kontrasygnata aktów urzędowych. Zakamycze 2004, s. 140.

${ }^{35} \mathrm{Tj}$. w dacie wejścia w życie noweli USP z 10 maja $2018 \mathrm{r}$. 
ca stan z daty Wyroku Trybunału Konstytucyjnego z dnia 24 października 2007 r., SK 7/06. Wobec powyższego zasadna jest konieczność zmiany Konstytucji RP poprzez dodanie prerogatywy prezydenckiej w postaci mianowania asesorów sądowych, jako analogicznej wobec obecnej prerogatywy Prezydenta do mianowania sędziów, albowiem w zakorzenionej tradycji polskiego konstytucjonalizmu to do prerogatyw głowy państwa należy powierzanie szeroko pojętych obowiązków sędziowskich.

\section{Urzeczywistnienie gwarancji praw zatrzymanego w postępowaniu karnym}

Normy o charakterze gwarancyjnym pozostają swoistym nudum ius, gdy w przepisach proceduralnych nie zapewniono odpowiednich mechanizmów do egzekucji zagwarantowanych praw. Sądowa kontrola zatrzymania zapewnia mechanizm realizacji gwarancji praw zatrzymanego, albowiem uczestnik postępowania karnego, inicjując sądową kontrolę zatrzymania w drodze zażalenia, dąży do respektowania jego uprawnień procesowych, których gwarancję realizuje sąd wyposażony w przymiot niezależności, niezawisłości i braku podległości wobec podmiotu, którego czynności dotyczy skarga odwoławcza (zażalenie) ${ }^{36}$. Ponadto funkcja prewencyjna sądowej kontroli zatrzymania sprzyja poprawności działania organów procesowych, które inaczej postępują, mając świadomość, że decyzja o zatrzymaniu i sama czynność zatrzymania podlegają sprawdzeniu przez sąd, który może stwierdzić nieprawidłowości i w trybie sygnalizacji uchybień z art. 19 k.p.k. może spowodować wyciągnięcie negatywnych konsekwencji w razie nie przestrzegania gwarancji procesowych osoby zatrzymanej $^{37}$.

Prawo do odszkodowania za bezprawne zatrzymanie unormowane w przepisie art. 41 ust. 5 Konstytucji RP realizowane jest w procesie karnym poprzez żądanie odszkodowania i zadośćuczynienia w wypadku niewątpliwie niesłusznego zatrzymania (art. 552 § 4 k.p.k.). Roszczenie można złożyć w sądzie okręgowym właściwym ze względu na miejsce, w którym nastąpiło zwolnienie zatrzymanego (art. 554 § 1 k.p.k.), o czym sąd okręgowy orzeka wyrokiem na rozprawie w składzie jednego sędziego

${ }^{36}$ Por. J. ZAGrodnik: Specyfika trybu kontroli postanowień o umorzeniu postępowania rejestrowego. Prok. i Pr. 2008, nr 9, s. 42; P. KęPA, J. ZaGrodniK: Sqdowa kontrola..., s. 27-28.

${ }^{37}$ Por. K. MARSZAE: Proces karny..., s. 81; szerzej o funkcjach sądowej kontroli organów ścigania karnego w postępowaniu przygotowawczym: A. GABERLE: Funkcje kontroli instancyjnej $w$ procesie karnym (zagadnienia podstawowe). W: Środki zaskarżenia $w$ procesie karnym..., s. 23-25; Z. DODA, A. GABERLE: Kontrola odwoławcza w procesie karnym. Warszawa 1997, s. 41-43. 
(art. 552 § 2 k.p.k.). Regulacja karnoprocesowa jest w tym względzie węższa od regulacji konstytucyjnej, lecz nie ogranicza praw osoby bezprawnie zatrzymanej, gdyż osoba ta może dochodzić swego roszczenia przed sądem cywilnym, wytaczając powództwo przeciwko Skarbowi Państwa o odszkodowanie za szkodę wyrządzoną przez niezgodne z prawem działanie lub zaniechanie przy wykonywaniu władzy publicznej (art. 417 $\S 1$ k.c. $)^{38}$.

Sąd sprawujący sądową kontrolę zatrzymania bada zgromadzony stan faktyczny i porównuje go z wzorcami określonymi w ustawie karnoprocesowej, i bierze pod uwagę kryteria wzorców konstytucyjnych i międzynarodowych, gdyż dotyczy to ograniczenia podstawowego prawa człowieka. Obowiązujący Kodeks postępowania karnego przewiduje sądową kontrolę legalności, zasadności i prawidłowości zatrzymania, lecz, jak pisał P. Kardas, nie przewiduje wyrażonej w art. 5 ust. 3 EKPC oraz w art. 41 ust. 3 Konstytucji RP gwarancji przeprowadzenia z urzędu kontroli legalności zatrzymania, przez co rzeczona sądowa kontrola uzależniona jest od inicjatywy zatrzymanego lub prokuratora, gdyż inicjowana jest przez wniesienie zażalenia zatrzymanego lub przez złożenie przez Prokuratora wniosku o zastosowanie tymczasowego aresztowania ${ }^{39}$.

Na mocy art. $246 \S 1$ k.p.k. zatrzymany, wnosząc zażalenie, może zainicjować sądową kontrolę zasadności, legalności i prawidłowości zatrzyma$\mathrm{nia}^{40}$. Konstytucyjne limity czasowe zatrzymania prowadzą do wniosku, że w razie przekroczenia 24-godzinnego terminu określonego w art. 41 ust. 3 Konstytucji RP oraz w świetle regulacji ustawy karnoprocesowej nie jest możliwe wydanie postanowienia o tymczasowym aresztowaniu $\mathrm{w}$ ramach incydentalnego postępowania zainicjowanego oddaniem do dyspozycji sądu, bowiem w ocenie P. Kardasa w takiej sytuacji prokurator musiałby złożyć kolejny wniosek rozpoznawany w nowym postępowaniu, a podejrzany odpowiadałby z wolnej stopy i nie można by go było zatrzymać na tej samej podstawie, chyba że pojawiłyby się nowe fakty czy też dowody ${ }^{41}$. Przemawiać ma za tym funkcja gwarancyjna, przejawiająca się w tym, że nie można $\mathrm{w}$ tym samym postępowaniu incydentalnym

${ }^{38}$ K. Sychta: Postępowanie sqdowe po uprawomocnieniu się orzeczenia. W: Proces karny. Przebieg postępowania. Wyd. II. Red. K. Marszat. Katowice 2012, s. 302, 305; R. STEFańsKI: Odpowiedzialność za niestuszne skazanie, niewatpliwie niestuszne oskarżenie, przedstawienie zarzutów lub zastosowanie nieizolacyjnego środka zapobiegawczego. Prok. i Pr. 2012, nr 12, s. 31-32.

${ }^{39}$ P. KARDAs: Uptyw określonego..., s. 131.

40 Szerzej o przedmiocie sądowej kontroli zatrzymania osoby zob. K. Marszat, J. ZAGRODNIK: Zatrzymanie właściwe z perspektywy sadowej kontroli postępowania przygotowawczego. W: Czynności dochodzeniowo-śledcze...; P. KĘPA, J. ZAGRODNIK: Sądowa kontrola..., s. 47-53.

${ }^{41}$ P. KaRdas: Uptyw określonego..., s. 140. 
orzec o zastosowaniu tymczasowego aresztowania wobec osoby, co do której nakazano bezwarunkowe zwolnienie ${ }^{42}$.

W toku sądowej kontroli zatrzymania sąd, w oparciu o wzorce ustawowe, konstytucyjne i konwencyjne, utrzyma zaskarżoną decyzję o zatrzymaniu albo stwierdzi nieprawidłowości, co pozwoli na zainicjowanie postępowania o odszkodowanie za niesłuszne zatrzymanie, które może być dochodzone w podstępowaniu karnym lub cywilnym. Prymat Konstytucji RP w polskim porządku prawnym, wyrażony w przepisie art. 8 ust. 1 Konstytucji RP, oznacza, że sąd w toku sądowej kontroli zatrzymania w razie uznania, że Konstytucja RP stanowi szerszą gwarancję dla uczestnika postępowania karnego niż akty niższego rzędu (np. akty prawa międzynarodowego, ustawy), ma prawo, a wręcz obowiązek zastosowania konstytucyjnego wzorca kontroli jako kryterium kontroli zatrzymania.

\section{Podsumowanie}

Wzorcami sądowej kontroli zatrzymania w polskim procesie karnym są normy Kodeksu postępowania karnego statuujące instytucję zatrzymania, normy statuujące działalność podmiotów przeprowadzających czynność zatrzymania oraz normy konstytucyjne i normy prawa międzynarodowego statuujacce gwarancje prawa osoby zatrzymanej. Sąd karny w toku sądowej kontroli zatrzymania nie dokonuje kontroli konstytucyjności prawa, zwanej niekiedy błędnie jako rozproszoną kontrolę konstytucyjności prawa, bowiem nie kontroluje norm prawnych i nie deroguje norm prawnych z systemu prawa, lecz zestawia ze sobą stan faktyczny ustalony w sprawie z wzorcami określonymi w aktach prawnych różnego rzędu. W sytuacji kolizji norm różnego rzędu sąd, realizując obowiązek bezpośredniego stosowania przepisów konstytucji wynikający z art. 8 ust. 2 Konstytucji RP w ramach sprawowania wymiaru sprawiedliwości, uwzględnia prymat konstytucyjnych wzorców (w tym wiążących wzorców z aktów prawa międzynarodowego, z tym zastrzeżeniem, że nadal Konstytucja RP stanowi najwyższe prawo w Rzeczypospolitej Polskiej). Sąd stosuje łącznie normy konstytucyjne i normy prawno-międzynarodowe, współegzystujące w ramach multicentrycznego systemu prawa, przy czym może wspierać się orzecznictwem sądu konstytucyjnego oraz sądów międzynarodowych. Sąd stosuje normy ustanawiające ustrojowe gwarancje praw zatrzymanego w postaci norm konstytucyjnych i norm prawno-międzynarodowych w drodze wykładni prokonstytucyjnej, współstosowania

\footnotetext{
${ }^{42}$ Ibidem, s. 142-143.
} 
norm rangi konstytucyjnej i norm niższego rzędu bądź posiłkując się kolizyjno-prawną zasadą lex superior derogat legi inferiori. De lege lata asesorzy sądowi mogą sprawować sądową kontrolę zatrzymania, o ile kontrola ta nie jest połączona $\mathrm{z}$ wnioskiem o zastosowanie tymczasowego aresztowania wobec osoby zatrzymanej i przekazanej do dyspozycji sądu. Zasadne jest poszerzenie w Konstytucji RP prerogatyw Prezydenta RP o mianowanie asesorów sądowych wobec dotychczasowej tradycji polskiego konstytucjonalizmu, przejawiającej się w prerogatywie głowy państwa do powierzania obowiązków sędziowskich i wobec silnego mandatu wyborczego i ustrojowego urzędu Prezydenta. Wydaje się, że wobec przeważającego stanowiska doktryny prawa konstytucyjnego oraz wobec treści art. 144 ust. 2 Konstytucji RP prerogatyw Prezydenta RP nie można wykładać rozszerzająco. W tym względzie nadto nie wydaje się, że ustawą zwykłą można regulować materię zastrzeżoną dla aktu konstytucyjnej rangi. Nowela USP z 10 maja 2018 r., uzależniając decyzję prezydenta o mianowaniu asesorów sądowych od nieskrępowanej decyzji Prezesa Rady Ministrów w przedmiocie kontrasygnaty, zdaje się wracać do stanu prawnego sprzed wejścia w życie Wyroku Trybunału Konstytucyjnego z dnia 24 października 2007 r., SK 7/06, wskutek czego zasadna wydaje się konieczność zmiany Konstytucji RP poprzez dodanie prezydenckiej prerogatywy do mianowania asesorów sądowych celem usunięcia wątpliwości konstytucyjnych wobec przywróconej instytucji asesora sądowego.

\section{Bibliografia}

\section{Literatura}

Balicki R.: Komentarz do art. 144 Konstytucji Rzeczypospolitej Polskiej. W: Konstytucja Rzeczypospolitej Polskiej. Komentarz. Red. M. Насzкоwsка. Warszawa 2014.

BanaszaK B.: Konstytucja Rzeczypospolitej Polskiej. Komentarz. Wyd. 2. Warszawa 2012.

Doda Z., Gaberle A.: Kontrola odwoławcza w procesie karnym. Warszawa 1997.

Eichstaedt K. W: Kodeks postępowania karnego. Komentarz. T. 1. Wyd. 2. Red. D. ŚwIECKI et al. Warszawa 2015, LEX.

Frankiewicz A.: Kontrasygnata aktów urzędowych. Zakamycze 2004.

GABERLE A.: Funkcje kontroli instancyjnej $w$ procesie karnym (zagadnienia podstawowe). W: Środki zaskarżenia w procesie karnym. Księga pamiatkowa ku czci prof. Zbigniewa Dody. Red. A. GaberLe, S. Waltoś. Kraków 2000.

GarLICKI L.: Polskie prawo konstytucyjne. Wyd. 15. Warszawa 2011.

GrZegorczyK T.: Kodeks postępowania karnego. Artykuty 1-467. T. 1. Wyd. 6. Warszawa 2014, LEX. 
Kalisz A.: Multicentryczność sytemu prawa polskiego a działalność orzecznicza Europejskiego Trybunatu Sprawiedliwości i Europejskiego Trybunatu Praw Człowieka. W: RPEiS 2007, R. LXIX, z. 4.

Kardas P.: Upływ określonego $w$ art. 41 ust. 3 Konstytucji $i w$ art. 248 \$2 k.p.k. 24-godzinnego terminu a możliwość wydania postanowienia o tymczasowym aresztowaniu. CPKINP 2008, R. XII, z. 1.

ŁĘTOWsKA E.: „Multicentryczność” systemu prawa i wykładnia jej przyjazna. W: Rozprawy prawnicze. Księga pamiątkowa Profesora Maksymiliana Pazdana. Red. L. OgiegŁo, W. PopioŁeK, M. Szpunar. Kraków 2005.

ŁĘTOWsKa E.: Multicentryczność współczesnego systemu prawa i jej konsekwencje. PiP 2005, z. 4.

Marszat K.: Proces karny. Zagadnienia ogólne. Wyd. 2 uzupełnione. Katowice 2013.

MARSZAŁ K., ZAGRODNIK J.: Zatrzymanie właściwe z perspektywy sadowej kontroli postępowania przygotowawczego. W: Czynności dochodzeniowo-śledcze i działania operacyjne policji a rola sądu w postępowaniu przygotowawczym. Materiały pokonferencyjne. Red. S. Lelental, J. KudreleK, I. Nowicka. Szczytno 2008.

Na straży państwa prawa. Trzydzieści lat orzecznictwa Trybunału Konstytucyjnego. Red. L. Garlicki, M. DerlatKa, M. WiąceK. Warszawa 2016.

PAPRZYCKI L. W: Komentarz aktualizowany do art. 1-424 ustawy z dnia 6 czerwca 1997 r. Kodeks postępowania karnego (Dz.U.97.89.555). Red. L. PAPrZYCKI, J. Grajewski, S. Steinborn. LEX.

SARnecki P.: Prezydent Rzeczypospolitej Polskiej. Komentarz do przepisów. Kraków 2000.

SARnecki P. W: Konstytucja Rzeczpospolitej Polskiej. Komentarz. T. 3. Warszawa 2003.

STEFAŃSKI R.: Odpowiedzialność za niestuszne skazanie, niewątpliwie niestuszne oskarżenie, przedstawienie zarzutów lub zastosowanie nieizolacyjnego środka zapobiegawczego. Prok. i Pr. 2012, nr 12.

Sychta K.: Postępowanie sadowe po uprawomocnieniu się orzeczenia. W: Proces karny. Przebieg postępowania. Wyd. II. Red. K. Marszat. Katowice 2012.

Wiliński P., Karlik P. W: Konstytucja RP, Komentarz do art. 1-86. T. 1. Red. M. SAFJAN, L. BoseK. Warszawa 2016. Legalis.

WiLIŃski P.: Proces karny w świetle konstytucji. Warszawa 2011.

ZAGRODNIK J.: Specyfika trybu kontroli postanowień o umorzeniu postępowania rejestrowego. Prok. i Pr. 2008, nr 9.

\section{Orzecznictwo}

Wyrok TK z dnia 11 czerwca 2002 r., SK 5/2002.

Wyrok TK z dnia 6 grudnia 2004 r., SK 29/2004.

Wyrok ETPC z dnia 22 września 1993 r., 27/1992/372/446, Klaas p. Niemcom.

Wyrok ETPC z dnia 4 grudnia 1995 r., 18896/91, Ribitsch p. Austrii.

Wyrok ETPC z dnia 20 maja 1998 r., 29462/95, Rehbock p. Slovenii.

Wyrok ETPC z dnia 28 lipca 1999 r., 25803/94, Selmouni p. Francji.

Wyrok ETPC z dnia 22 maja 2001 r., 22279/93, Altay p. Turcji.

Wyrok ETPC z dnia 12 kwietnia 2007 r., 48130/99, Ivan Vasilev p. Bułgarii.

Wyrok ETPC z dnia 13 stycznia 2009 r., 15562/02, Lewandowski i Lewandowska p. Polsce. 


\section{Źródła internetowe}

http://isp.policja.pl/isp/prawa-czlowieka-w-poli/orzecznictwo/1351,Sprawa-Le wandowski-i-Lewandowska-przeciwko-Polsce.html [dostęp: 30.07.2017].

http://www.hfhr.pl/wazne-orzeczenia-etpcz-w-polskich-sprawach-3/ [dostęp: 30.07.2017].

http://www.sn.pl/orzecznictwo/Orzecz_Euro_Karne/Orzecz_Euro_Karne_01-02_2010. pdf [dostęp: 30.07.2017].

KęPA P., ZAGRODNIK J.: Sądowa kontrola organów ścigania karnego $w$ postępowaniu przygotowawczym. Śląska Biblioteka cyfrowa. Źródło: https://www.sbc. org.pl/dlibra/publication/269652/edition/255095/content?ref=desc [dostęp: 7.01.2018]. 